\title{
Blood Plasma Metabolic Profile of Aberdeen Angus Bulls during Postnatal Ontogenesis
}

\author{
Aleš Pavlík ${ }^{1}$, Pavel Jelínek ${ }^{1}$, Martin Matějíček ${ }^{1}$, Josef Illek² \\ ${ }^{1}$ Department of Animal Morphology, Physiology and Genetics, Mendel University \\ in Brno, Czech Republic \\ ${ }^{2}$ University of Veterinary and Pharmaceutical Sciences Brno, Czech Republic
}

Received June 25, 2009

Accepted December 3, 2009

\begin{abstract}
Selected indicators for the metabolic profile of blood plasma in 22 Aberdeen Angus bulls reared by the extensive method were monitored during postnatal development (from 4 to 564 days of age), including total proteins, albumin, urea, creatinine, glucose, cholesterol, triacylglycerols, bilirubin, alkaline phosphatase, alanine transaminase, aspartate transaminase, tyroxin, triiodothyronine, calcium, inorganic phosphorus, magnesium, potassium, sodium, chlorides, copper, zinc and iron. In assessing the relationship of age to the indicators of the internal environment, values of correlation coefficients for total proteins $(\mathrm{r}=-0.70 ; p<0.01)$, albumin $(\mathrm{r}=-0.56 ; p<0.01)$, urea $(\mathrm{r}=-0.73 ; p<0.01)$, glucose $(\mathrm{r}=-0.38 ; p<0.01)$ and triiodothyronine $(\mathrm{r}=-0.82 ; p<0.01)$ were established. Significant relationships were shown between the temperature of the external environment and the amount of total proteins $(\mathrm{r}=-0.38 ; p<0.01)$, urea concentration $(\mathrm{r}=-0.41$; $p<0.01), \operatorname{ALP}(\mathrm{r}=0.58 ; p<0.01)$ and $\operatorname{ALT}(\mathrm{r}=0.45 ; p<0.01)$ activity. Temperature also showed a significant impact on the concentration of $\mathrm{P}(\mathrm{r}=0.57 ; p<0.01), \mathrm{K}(\mathrm{r}=-0.69 ; p<0.01)$ and $\mathrm{Zn}(\mathrm{r}=0.33 ; p<0.01)$. The work yields important information on changes in the indicators of the metabolic profile of the blood plasma of bulls during postnatal development under defined nutritional and temperature conditions that can be used as reference values for evaluating health status as well as nutrition level.
\end{abstract}

Beef cattle, internal environment, blood plasma nutrition status

Evaluating the nutrition and health status of beef cattle raised in extensive conditions is a necessary prerequisite for effective production of quality beef. In order to precisely examine the relationship between dietary and production factors, the obtaining of detailed information on changes in the internal environment of animal during individual phases of the animals' production life is essential (Rusel and Wright 1983; Cavestany et al. 2005). Changes in the concentrations of different metabolites in the blood of extensively reared cattle can be caused, for example, by qualitative or quantitative restrictions in feeding (Agenas et al. 2006; Cooke et al. 2008; Ndlovu et al. 2009). The quality of grazing vegetation can be changed depending on changes in climatic conditions (Chimonyo et al. 2000; Brown and Adjei 2001). An influence of rearing technology on blood metabolic profile is also evident (Philips et al. 1989; Myers et al. 1999; Coppo et al. 2002; Hickey et al. 2003; Blanco et al. 2009). Influence of temperature, season and breed on the indicators of the internal environment was studied, too (Doornenbal et al. 1988; Thrall et al. 2004; Grundwaldt et al. 2005; Yokus and Cakir 2006; Ndlovu et al. 2009). The concentration of metabolites in animals' blood is an important indicator associated with the production of particular animal products (Rueg et al. 1992; Casasus et al. 2002; Ban-Tokuda et al. 2007). Determining indicators of the metabolic profile during the breeding season is helpful in diagnosing metabolic problems in animals (Jagos et al. 1985; Verheyen et al. 2007). The knowledge of physiological processes can contribute to achieve greater production at given levels of genetic potential of the reared animals (Pereira et al. 2008; Sasaki et al. 2002).

The goal of this work was to determine selected indicators of the metabolic profile in

Address for correspondence:

Ing. Aleš Pavlík, PhD.

Department of Morphology, Physiology and Genetics

Mendel University of Agriculture and Forestry

Zemedelska 1, 61300 Brno, Czech Republic
Phone: +420545133148

Fax: +420545133176

E-mail: pavlik@mendelu.cz

http://www.vfu.cz/acta-vet/actavet.htm 
the blood plasma of Aberdeen Angus (AA) bulls during post-natal development. Obtained indicators of metabolic profile can be used for assessing health and nutrition status of animal and for early detection of production disorders that are often a side effect in extensive rearing.

\section{Materials and Methods}

The experiment was conducted on a farm in the foothills of the Orlické Mountains. The elevation in this area is around $500 \mathrm{~m}$ a.s.l., and the total annual precipitation is on average $728 \mathrm{~mm}$ per year. The average monthly air temperatures and relative air humidity are indicated in Fig. 1 .

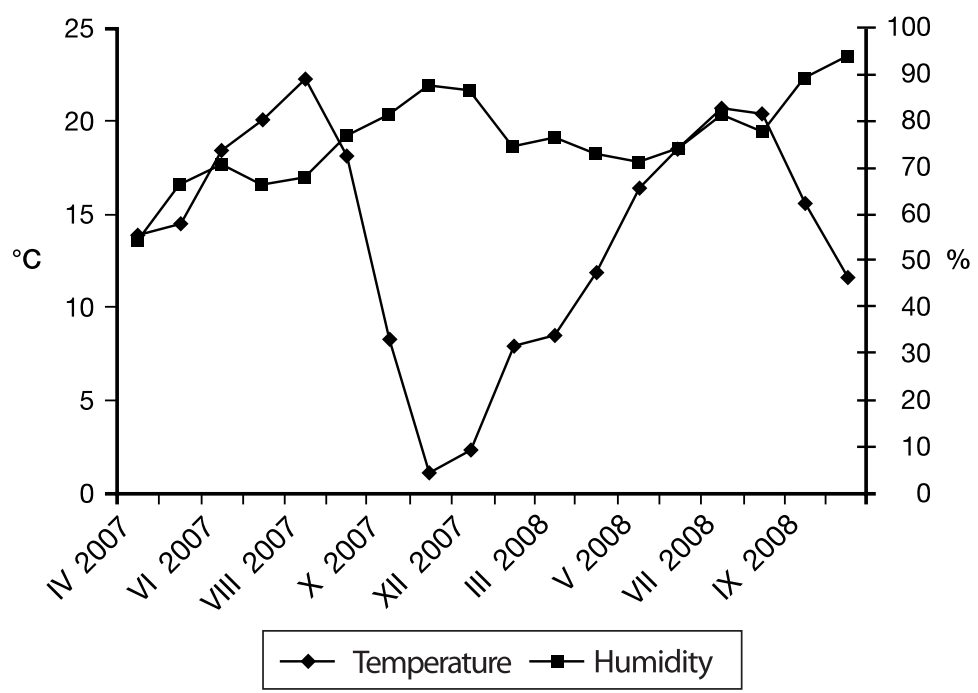

Fig. 1. Average air temperatures and relative air humidity during the examined period

Twenty-two Aberdeen Angus bull calves born between February and April 2007 were selected for experiment. These animals were divided into two groups of 11 according to the date of birth so that the age difference among two groups of animals was minimal. During the growing period at the beginning of experiment, the feeding ration for the animals was composed primarily of their mothers' milk and starter, with gradual transition to grazing and supplemental hay. After the grazing period, the bulls were transferred to a feedlot, where the basis of the feeding ration was composed of corn silage, hay and granulated distiller's grains. The content of standard nutrients in the feeding rations is presented in Table 1. At 4 days of age and subsequently at the average ages of $56,95,116,155,168,207,252,291,329,368,434,473,525$ and 564 days, blood was taken from the subcaudal vein using the Hemos extraction system. The blood samples were stabilised with heparin and centrifuged at $1,200 \mathrm{~g}$ for $15 \mathrm{~min}$. The blood plasma was held at a temperature of $-20{ }^{\circ} \mathrm{C}$ until analysed. From the blood plasma, the concentrations of the following indicators of the metabolic profile were determined: total proteins (TP), albumin, urea, creatinine, glucose (Glu), cholesterol (Chol), triacylglycerols (TAG), bilirubin (Bil), alkaline phosphatase (ALP), alanine transaminase (ALT), aspartate transaminase (AST), creatine kinase (CK), tyroxin (T4), and triiodothyronine (T3). Among mineral elements, concentrations of calcium $(\mathrm{Ca})$, inorganic phosphorus $(\mathrm{P})$, magnesium $(\mathrm{Mg})$, potassium $(\mathrm{K})$, sodium $(\mathrm{Na})$, chlorides $(\mathrm{Cl})$, copper $(\mathrm{Cu})$, zinc $(\mathrm{Zn})$ and iron $(\mathrm{Fe})$ were measured. Biochemical indicators were analysed on an XT20i automatic analyser (Thermo Fisher Scientific, Finland). T3 and T4 contents were determined using an Immulite automatic analyser (DPC, USA) and currently available commercial kits (Biovendor-Laboratorní medicína, a.s., ČR).

Statistical analysis of the obtained data was performed using the STATISTICA 8.0 programme by singlefactor analysis of variance for animal age. ANOVA was followed by post-hoc Fisher's LSD test for pairwise comparisons where appropriate. Evaluation of the interdependence between the animals' age, temperature of the external environment and individual indicators of the animals' internal environment was conducted using a correlation coefficient at the level of probability $(p<0.01)$. 


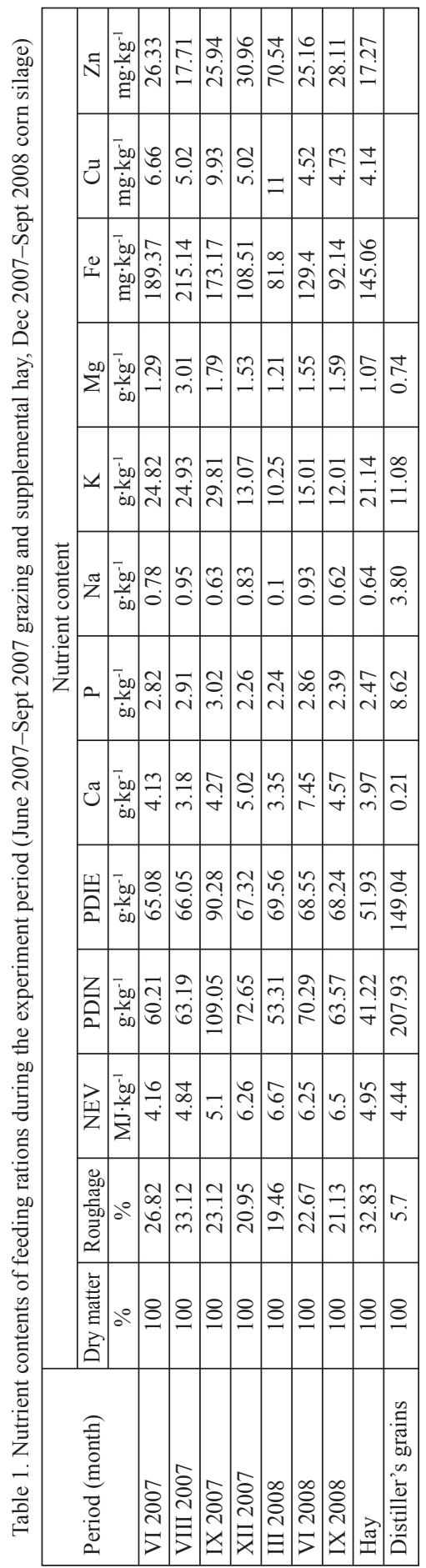

\section{Results}

Average values of the concentrations of metabolic profile indicators are given in Tables 2 and 3. A relationship was detected between the temperature of the environment and the concentration of total proteins $(\mathrm{r}=-0.38 ; p<0.001)$. During the monitored period, changes $(\mathrm{F}(12,141)=17.820 ; p<0.001)$ were recorded in the content of total proteins in the bulls' blood plasma. The lowest average values of total proteins were determined at the start of the experiment, in the so-called natal calves. Subsequently, an increase $(p<0.05)$ of total proteins was recorded up to 252 days of age. At 329 and 368 days, a drop $(p<0.01)$ of values was observed, followed by their further increase until the end of the monitored period. The same progression of changes was recorded in the concentration of plasma albumin. The amount of urea in blood plasma did not change dramatically during the experiment. The temperature of the environment had a decisive influence on the concentration of urea in blood plasma $(\mathrm{r}=-0.41$; $p<0.001)$. Average values of urea fluctuated between 3.42 and $5.37 \mathrm{mmol} \cdot \mathrm{l}^{-1}$ with an increase $(p<0.05)$ recorded at 252 days of age. At this age, conclusively higher values of creatinine were seen in blood plasma. Changes in concentration of plasma glucose were recorded during the experiment $(\mathrm{F}(12,141)=5.962 ; p<0.01)$. A rapid increase $(p<0.01)$ of glucose concentration was detected in bull calves in the period from birth until 56 days of age with subsequent modest fluctuation until the end of the experiment.

For assessing the relationship between age and the indicators of the internal environment, correlation coefficient values were established for albumin $(\mathrm{r}=$ $-0.56 ; p<0.01)$, total proteins $(\mathrm{r}=-0.70 ; p<0.01)$, urea $(\mathrm{r}=-0.73 ; p<0.01)$ and glucose $(\mathrm{r}=-0.38$; $p<0.01)$. The concentration of total cholesterol increased significantly after birth $(p<0.01)$, and its level subsequently decreased with slight fluctuation until the end of the monitored period. An increase $(p<0.05)$ was recorded in bulls at 168 days of age. The content of triacylglycerols showed a decreasing tendency $(\mathrm{F}(12,141)=3.359 ; p<0.001)$ from the start of observation. In contrast to plasma cholesterol, high concentrations $(0.324$ to 0.370 mmol $\cdot 1^{-1}$ ) were observed at the start of observation compared to the average values seen at an older age. The highest amount of bilirubin in the bulls' blood plasma was also observed at the start of the 


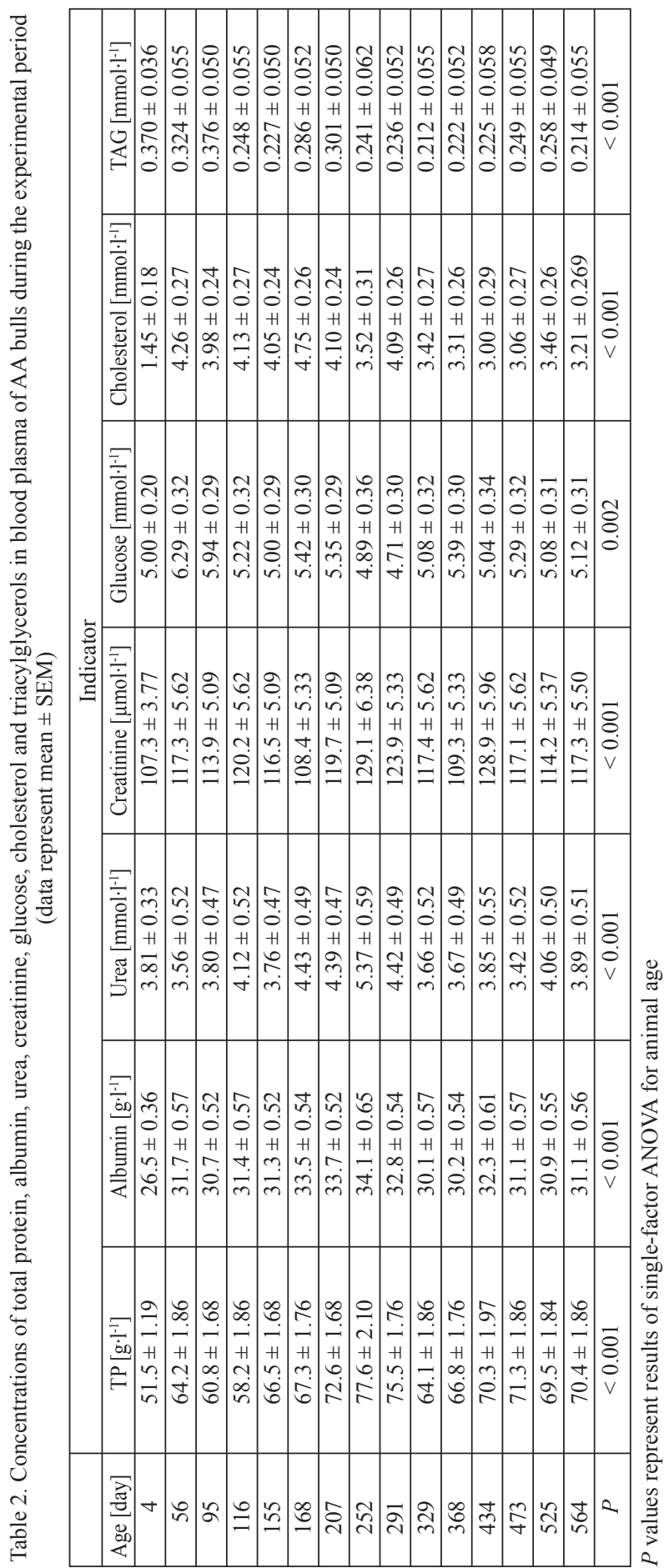

experiment. In the subsequent period, its concentration did not change significantly. The highest average values for alkaline phosphatase activity were recorded from birth to 95 days of age (3.63 to $\left.4.04 \mu \mathrm{kat} \cdot \mathrm{l}^{-1}\right)$. From 116 days of age, ALP activity decreased $(\mathrm{F}(12,141)=4.212 ; p<$ $0.001)$ until the end of the experiment. The lowest values for ALT activity were observed in bull calves after birth. These values then increased $(\mathrm{F}(12,141)=39.272 ; p<$ $0.001)$ until 329 days of age. From this time, catalytic ALT activity fluctuated between 0.53 and $0.56 \mu \mathrm{kat} \cdot \mathrm{I}^{-1}$ until the end of the monitored period. The catalytic concentration of AST in bulls' blood plasma $(\mathrm{F}(12,141)=9.332$; $p<0.01)$ showed a similar development. Correlation coefficients were calculated for age and catalytic ALP $(\mathrm{r}=-0.77 ; p<0.01)$, ALT $(\mathrm{r}=$ $0.69 ; p<0.01)$, and AST $(\mathrm{r}=$ $-0.41 ; p<0.01)$ activity. The temperature of the external environment also affected ALP and ALT activity $(\mathrm{r}=$ 0.58 and $\mathrm{r}=-0.45 ; p<0.001)$. Creatine kinase activity did not change dramatically from the beginning of the experiment through 155 days of age. A decrease $(p<0.05)$ in catalytic concentration was recorded in the animals from that time until 291 days of age with a subsequent increase ( $p$ $<0.05$ ) until 564 days of age. The highest concentration of triiodothyronine was observed in bull calves after birth (6.85 nmol $\left.\cdot \mathrm{l}^{-1}\right)$. With increasing age, its level decreased through 155 days of age $(F(12,141)$ 


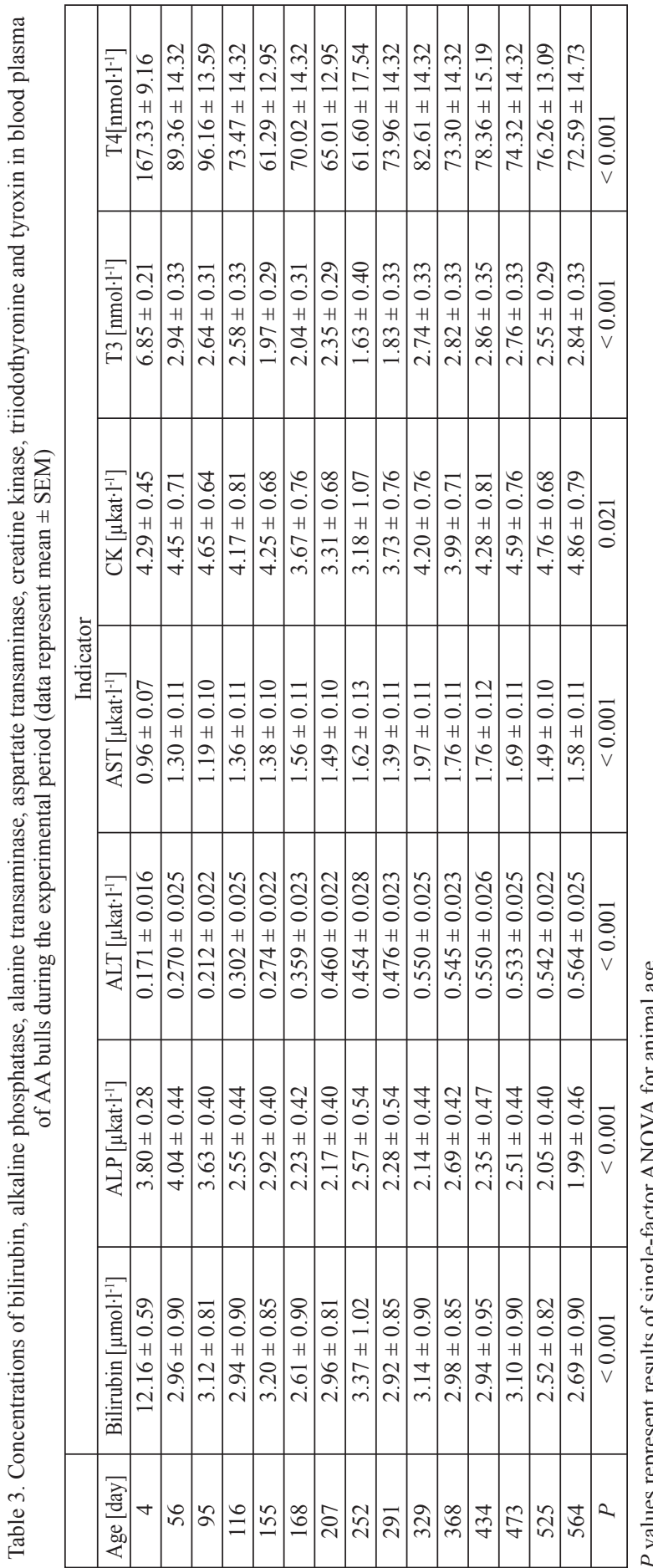

$=34.189 ; p<0.001)$. Slight

fluctuation was recorded from day 168 to 291. At 329 days of age, average values rose but subsequently did not change through the end of the experiment. The correlation coefficient $\mathrm{r}=$ $-0.82(p<0.01)$ expresses the interdependence of triiodothyronine concentration with the animals' age. A similar progression of changes was seen during the experiment in the concentration of tyroxin $(\mathrm{F}$ $(12,141)=9.141 ; p<0.001)$.

The contents of micro- and macro-elements in blood plasma during the monitored period are given in Table 4 . The plasma concentration of calcium decreased, with slight fluctuation, from birth until the end of experiment. Phosphorus in the blood plasma of monitored bulls showed increased average values in the period from 56 to 116 days of age. It increased thereafter until day 168 , at which time it decreased until day 291. Concentration of magnesium in blood plasma slighty decreased from birth until 155 days of age, then it increased until 291 days of age, but thereafter again decreased $(\mathrm{F}$ $(12,141)=13.031 ; p<0.001)$. In the first half of experiment, the concentration of plasma potassium did not change significantly; a drop $(p<0.01)$ in its average concentration was recorded from 368 to 473 days of age. The amount of sodium in the bulls' blood plasma fluctuated in a range of 139.4-144.9 $\mathrm{mmol} \cdot \mathrm{l}^{-1}$ during the experiment. A marked decrease $(p<0.01)$ in the concentration of chlorides 


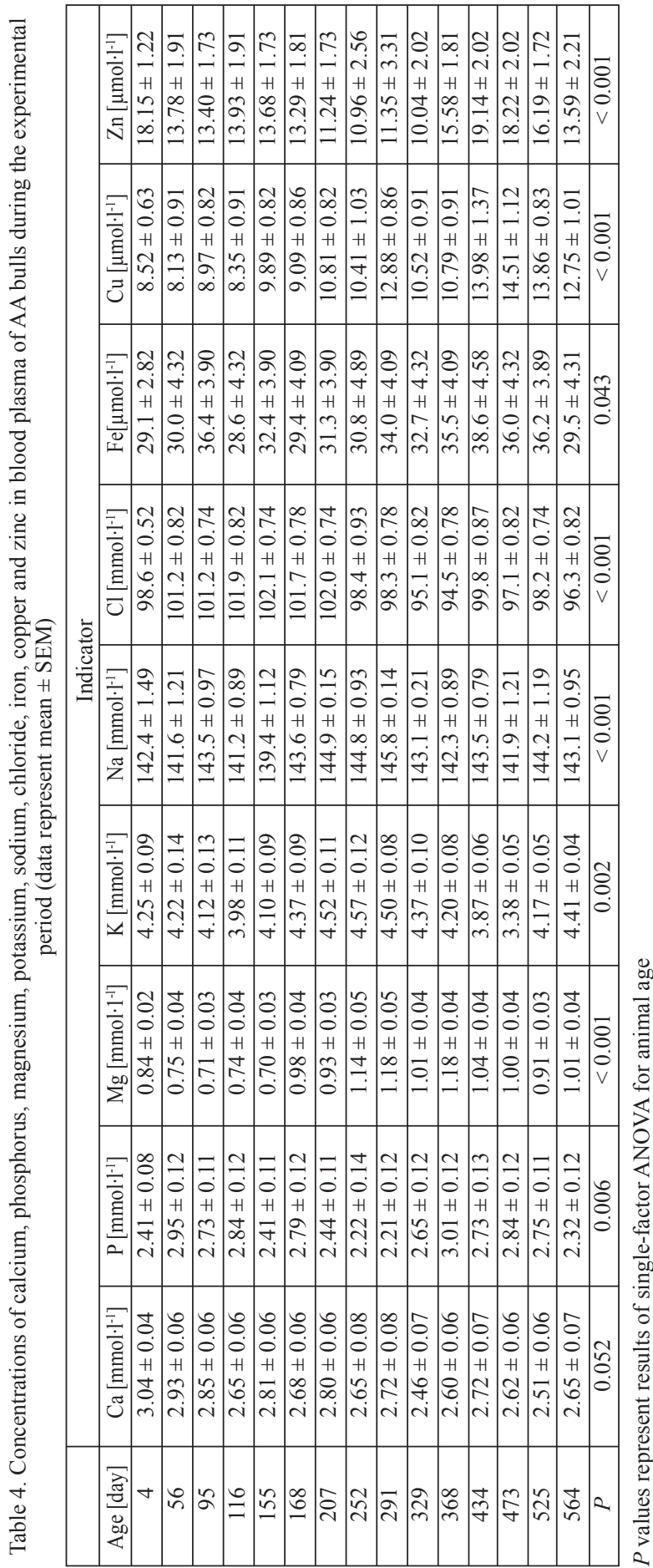

was recorded from 252 to 434 days of age. The concentration of plasma iron increased from the start of the experiment $\left(29.1 \mu \mathrm{mol} \cdot \cdot^{-1}\right)$ through 525 days of age $\left(36.2 \mu \mathrm{mol} \cdot \mathrm{l}^{-1}\right)$. Similar development was recorded for copper concentration in the bulls' blood plasma with a significant increase $(p<0.05)$ at 434 days of age. In the same period, there was a significant rise in the concentration of zinc. Unlike that of plasma copper, the concentration of zinc decreased from the beginning of experiment. Conclusive relationships $\quad(p<0.001)$ with the animals' age were recorded for $\mathrm{Ca}, \mathrm{P}, \mathrm{Mg}$ and $\mathrm{Zn}$ $(\mathrm{r}=-0.38, \mathrm{r}=-0.33, \mathrm{r}=0.32$ and $\mathrm{r}=-0.53)$. A conclusive relationship was also noted between the temperature of the external environment and the concentration of $\mathrm{P}(\mathrm{r}=0.57)$, $\mathrm{K}(\mathrm{r}=-0.69)$ and $\mathrm{Zn}(\mathrm{r}=0.33)$ (Table 5).

\section{Discussion}

As reported by Chimonyo et al. (2000), changes in the amount of total proteins in bulls' blood plasma can be caused to a certain extent by variability in the quality of feedstuffs provided. Among the factors increasing the amount of proteins, a prevalence of internal parasites in the period from December to March tends to be included owing to the increase in the globulin fraction (Thrall etal.2004; Grunwaldt et al. 2005). In our experiment, the amount of total proteins increased from September to December. Considering that preventive measures against parasitic illnesses were taken, 
Table 5. The correlation of the internal evironment indicators, age and temperature. Values presented in bold face are significant in $p<0.01$

\begin{tabular}{|l|c|c|c|c|c|c|c|c|}
\hline & TP & Abumin & Urea & Crea & Glu & Chol & TAG & Bilirubin \\
\hline Age & $\mathbf{0 . 7}$ & $\mathbf{0 . 5 6}$ & $\mathbf{0 . 7 3}$ & $\mathbf{0 . 4 6}$ & $\mathbf{- 0 . 3 8}$ & 0.05 & $\mathbf{- 0 . 4 2}$ & 0.01 \\
\hline Temperature & $\mathbf{- 0 . 3 8}$ & -0.32 & $\mathbf{- 0 . 4 1}$ & -0.14 & 0.22 & -0.19 & 0.31 & 0.05 \\
\hline & ALP & ALT & AST & CK & T3 & T4 & Ca & P \\
\hline Age & $\mathbf{- 0 . 7 7}$ & $\mathbf{0 . 6 9}$ & $\mathbf{0 . 4 1}$ & 0.29 & $\mathbf{- 0 . 8 2}$ & -0.29 & $\mathbf{- 0 . 3 8}$ & $\mathbf{- 0 . 3 3}$ \\
\hline Temperature & $\mathbf{0 . 5 8}$ & $\mathbf{- 0 . 4 5}$ & -0.06 & -0.13 & $\mathbf{0 . 5 1}$ & 0.10 & 0.16 & $\mathbf{0 . 5 7}$ \\
\hline & $\mathrm{Mg}$ & $\mathrm{K}$ & $\mathrm{Na}$ & $\mathrm{Cl}$ & $\mathrm{Fe}$ & $\mathrm{Cu}$ & $\mathrm{Zn}$ & \\
\hline Age & $\mathbf{0 . 3 2}$ & 0.29 & 0.15 & -0.35 & 0.05 & -0.08 & $\mathbf{- 0 . 5 3}$ & \\
\hline Temperature & -0.07 & $\mathbf{- 0 . 6 9}$ & 0.12 & 0.58 & -0.12 & -0.03 & $\mathbf{0 . 3 3}$ & \\
\hline
\end{tabular}

we assume that the increase in the protein content is due to a higher amount of nitrogen compounds in the feed ration in this period. This hypothesis also supports the increase in the concentration of albumin and urea during the same period. Plasma albumin is a sensitive nutritional indicator of protein status (Doornenbal et al. 1988; Slobodianik et al. 1999). The concentration of plasma urea also reflects changes in the metabolism of proteins, whereby changes in the amount of total proteins and albumin in the blood can be explained (Payne 1987). This statement is also supported by the work of Godden et al. (2001), Brown and Adjei (2001), Nazi et al. (2003), Thrall et al. (2004) as well as Grunwaldt et al. (2005), who found out that the concentration of urea in blood plasma depends on the amount of ingested proteins in the feed and their degradation in the rumen, the dietary composition of ingested amino acids, and the capacity for degradation of saccharides in the rumen. In our experiment, higher average values for the concentration of urea were recorded in bulls, corresponding with the findings of Otto et al. (2000). Byers and Moxon (1980) set an optimum concentration of urea in the blood plasma of fattened beef cattle in the range $1.8-2.5 \mathrm{mmol}^{-1} \mathrm{l}^{-1}$ and pointed to over-supplied intake of nitrogen compounds leading to higher values of urea. A lower concentration of urea may be due to a higher capacity to convert nitrogen into amino acids and proteins that leads to faster growth of the organism, as further reported by Otto et al. (2000). Increased concentration of plasma creatinine is recorded during a period of insufficient nutrition in animals, when skeletal muscles are used as a source of energy (Thrall et al. 2004). In our study, an increase in the concentration of creatinine in bulls' blood plasma was recorded during the summer and winter months. Similar results were found by Ndlovu et al. (2007). Summer and winter are periods of lower quality nutrition for grazing beef cattle (Chimonyo et al. 2000; Grundwaldt et al. 2005).

During the experiment, glucose concentration changed with fluctuating tendency. Cabaraux et al. (2004) indicated a decrease in the concentration of glucose with age. They attributed this phenomenon to a rise in the concentration of plasma insulin due to the increase in feed intake. In our experiment, glucose concentration decreased during the summer and winter months. This corresponds with the findings of Chimonyo et al. (2000), Grunwaldt et al. (2005), Fraser et al. (2009) and Ndlovu et al. (2009). These authors attributed decrease in the concentration of glucose to insufficient nutrition in this period. Holenbeck et al. (2006) recorded an average value of glucose concentration of $4.77 \mathrm{mmol} \cdot \mathrm{l}^{-1}$ in Aberdeen Angus bulls and supposed that a decrease of glucose concentration may be due to higher respiration rates of bulls during the hot season. Ban Tokuda et al. (2007) pointed to the decreasing concentration of glucose during fattening, which does not entirely correspond with our results as the concentration of plasma glucose in bulls during fattening did not change significantly.

Ban Tokuda et al. (2007) noted that the concentration of total cholesterol in bull calves 
increases until three months of age. Similarly, they detected an increase in the concentration of TAG until five months of age, followed by its decrease. In our observations, the influence of increase in the concentrations of plasma cholesterol and TAG was also recorded in the period of up to five months of age, with a subsequent decrease until the end of the experiment. Certain studies connect an increased level of cholesterol with a better energy balance (Cavestany et al. 2005). Thrall et al. (2004) regarded the higher concentration of cholesterol in the blood plasma of cattle as an indicator of higher energy reserves. On the other hand, there is a hypothesis that it is the result of energy insufficiency (Bruss 1997). According to Margollese (1983), the concentration of cholesterol increases as a result of lipids mobilisation due to the activity of glucagon or as a result of an increase in the synthesis of plasma lipoproteins. The higher concentration of cholesterol at the beginning of experiment may be attributed to its relationship to the amount of plasma glucose. As indicated by Reynolds et al. (2001), a higher concentration of glucose in blood plasma stimulates the secretion of insulin, which reduces the concentration of cyclic adenosine monophosphate (cAMP), thereby stimulating the synthesis of cholesterol. Pavlik et al. (2009) recorded a positive relationship between the concentration of plasma cholesterol and weight gain while they detected a significant decrease in the concentration of total cholesterol along with a drop in weight gain during weaning. According to Ban Tokuda et al. (2007), this drop may be due to the method of reducing feed intake because cholesterol is used as a source of energy for ruminant animals (Adachi et al. 1997). These findings do not correspond with the results of our experiment, as no significant drop in the concentration of cholesterol was recorded during the weaning period in the interval from 250 to 290 days of age.

Ndlovu et al. (2009) pointed to the higher concentration of metabolites (glucose, cholesterol) related to nutrition for breeds adapted to an insufficiency of quality grazing vegetation. They explained this phenomenon as a certain physiological adaptation of energy need when searching for and obtaining nutrition. In their work, they found a considerably lower concentration of these metabolites in the Aberdeen Angus breed compared with our results. These differences can be explained by the quite different climatic conditions in their experiment.

The catalytic concentration of ALP decreased from the beginning of experiment until the animals were one year old. This tendency is also evident in other species and is the result of rapid growth in young animals, as ALP concentration becomes elevated during the mineralisation of bone tissue when it is released from growing bones and enters the blood (Kaneko et al. 1997; Knowles et al. 2000). Otto et al. (2000) found a correlation between age and ALP $(r=0.649)$ in their study. Ndlovu et al. (2009) supposed that higher ALP activity is connected with a higher ratio of bone tissue to muscle tissue. Pavlik et al. (2009) observed an increase in catalytic ALT and AST activity during the weaning of Gasconne bull calves at approximately 270 days of age together with a significant drop in growth intensity. The reason for ALP and AST increased concentration. can be higher pressure on the liver due to insufficient nutrition connected with negative energy and nitrogen balance (Parra et al. 1999; Cavestany et al. 2005). In our experiment, as in the work of Ndlovu et al. (2009), no impact of weaning on the increase of the concentration of these enzymes was seen. Activity of ALT and AST enzymes increased during the experimen in connection with the age of the animals.

Daix et al. (2008) indicated a T3 value of $1.16 \mathrm{nmol} \cdot \mathrm{l}^{-1}$ and a T4 value of $124.8 \mathrm{nmol} \cdot \mathrm{l}^{-1}$ for Aberden Angus bulls aged 18 months. They detected significantly lower average values for the Belgian Blue breed, and they explained this difference by the lower intensity of basal metabolism, which to a certain extent can also explain the better conversion of food by this breed. In our experiment, the average concentrations of these hormones fluctuated in ranges of 1.63-2.94 $\mathrm{nmol} \cdot \mathrm{l}^{-1}$ for T3 and 61.6-96.1 $\mathrm{nmol} \cdot \mathrm{l}^{-1}$ for T4. A markedly higher 
concentration of these hormones was observed in the period after birth. These high concentrations are most likely connected with the importance of the thyroid hormones in differentiating cells during intrauterine development and shortly after birth.

Individual indicators of the mineral profile of blood plasma were found in our experiment within physiological ranges mentioned by, e.g., Whitaker et al. (1999) and Grunwaldt et al. (2005). The concentration of plasma calcium did not change significantly during the monitored period despite the higher content of $\mathrm{Ca}$ in the winter feeding ration. Similarly as in the study by $\mathrm{Ndlovu}$ et al. (2009), season did not prove to have an effect on concentration of $\mathrm{Ca}$ as indicated by McDowell et al. (2005). The average values of $\mathrm{Ca}$ observed in our experiment were higher compared to the values determined by Farver (1997). Overton and Waldron (2004) and Ndlovu et al. (2009) found lower concentrations of phosphorus and magnesium in the blood plasma of AA bulls in the winter period. Our results are in agreement with these finding, because the lower concentration of phosphorus was found in bulls in December when they were 252 and 291 days old. But in case of magnesium, different results were obtained. Farver (1997) and Ndlovu et al. (2009) found a concentration of $\mathrm{P}$ between 1.2 and $2.3 \mathrm{mmol} \cdot \mathrm{l}^{-1}$. These values are lower compared to our results. But the concentration of plasma magnesium $\left(0.6-1.2 \mathrm{mmol} \cdot \mathrm{l}^{-1}\right)$, however, fully corresponds with our results. Despite the higher amounts of iron and copper in the grazing area at the beginning of experiment, a higher concentration of these elements was found in the bulls' blood plasma only in the second half of the experiment. An increase in the concentration of plasma zinc was found in bulls in age from 329 to 434 days, during which time a higher amount of zinc was included in the feeding ration. The values of zinc in bulls detected in our experiment corresponded to the physiological range set by Suttle (1993).

In this experiment, the ranges of average values for indicators of the internal environment of Aberdeen Angus bulls from birth to their slaughter were established. Significant influence of age and environmental temperature was found for certain indicators of the blood plasma's metabolic profile. Changes in the concentration of established indicators correspond to the levels of metabolic processes in animals during individual phases of their production lives. This results can be used in assessing health and nutritional status of animals as well as for early detection of production disorders in beef cattle raised in extensive breeding.

\section{Metabolický profil krevní plazmy býků plemene Aberdeen Angus v průběhu postnatálního vývoje}

U 22 býků plemene Aberdeen Angus chovaných extenzivním zpo̊sobem byly v průběhu postnatálního vývoje (od 4 do 564 dnů věku) sledovány vybrané ukazatele metabolického profilu krevní plazmy a to celkové bílkoviny, albumin, urea, kreatinin, glukóza, cholesterol, triacylglyceroly, bilirubin, alkalická fosfatáza, alaninaminotransferáza, aspartátaminotransferáza, kreatin kináza, tyroxin, trijodtyronin, vápník, anorganický fosfor, hořčík, draslík, sodík, chloridy, měd', zinek a železo. Při hodnocení vztahu věku k ukazatelům vnitřního prostředí zvířete byly stanoveny hodnoty korelačních koeficientů u celkových bílkovin $(\mathrm{r}=-0,70 ; p<0,01)$, albuminu $(\mathrm{r}=-0,56 ; p<0,01)$, močoviny $(\mathrm{r}=-0,73 ; p<0,01)$, glukózy $(\mathrm{r}=-0,38 ; p<0,01)$ a trijodtyroninu $\mathrm{r}=-0,82(p<0,01)$. Byl zjištěn průkazný vztah mezi teplotou vnějšího prostředí a obsahem celkových bílkovin $(\mathrm{r}=-0,38 ; p<0,01)$, koncentrací močoviny $\mathrm{r}=-0,41 ; p<0,01)$, aktivity ALP $(\mathrm{r}=0,58$; $p<0,01)$ a ALT $(\mathrm{r}=0,45 ; p<0,01)$. Významný vliv teploty byl zaznamenán také $\mathrm{u}$ koncentrace $\mathrm{P}(\mathrm{r}=0,57 ; p<0,01), \mathrm{K}(\mathrm{r}=-0,69 ; p<0,01)$ a $\mathrm{Zn}(\mathrm{r}=0,33 ; p<0,01)$. Práce přináší důležité informace o změnách ukazatelů metabolického profilu krevní plazmy býků v průběhu postnatálního vývoje při definovaných podmínkách výživy a teploty prostředí, které lze využít jako referenční hodnoty pro hodnocení zdravotního stavu zvírete i kvality výživy. 


\section{Acknowledgement}

The present study was supported by the project of National Agency for Agricultural Research no. QH 71156.

\section{References}

Adachi K, Kawano H, Tsuno K, Nomura Y, Katsura N, Arikawa A, Tsuji A, Onimaru T 1997: Values of the serum components in Japanese Black Beef steers at farms with high productivity and low frequencies of disease and death in Miyazaki Prefecture. J Vet Med Sci 59: 873-877

Agenas S, Heath MF, Nixon RM, Wilkinson JM, Phillips CJC 2006: Indicators of under nutrition in cattle. Anim Welfare 15: 149-160

Ban-Tokuda T, Orden EA, Bariio AN, Lapitan RM, Delevaud C, Chilliard Y, Fujihara T, Cruz LC, Homma H, Kanai F 2007: Effects of species and sex on plasma hormone and metabolite concentrations in crossbred Brahman cattle and crossbred water buffalo. Livest Sci 107: 244-252

Blanco M, Casasus I, Palacio J 2009: Effect of age at weaning on the physiological stress response and temperament of two beef cattle breeds. Animal 3: 108-117

Brown WF, Adjei MB 2001: Urea and (or) feather meal supplementation for yearling steers grazing limpograss (Hemarthria altissima var. 'Floralta') pasture. J Anim Sci 79: 3170-3176

Bruss ML 1997: Lipids and ketones. In: Kaneko J, Harvey W, Brus M (Eds), Clinical Biochemistry of Domestic Animals, pp. 86-105. Academic Press, New York

Byers FM, Moxon AL 1980: Protein and selenium levels for growing and finishing beef cattle. J Anim Sci 50: $1136-1144$

Cabaraux JF, Dufrasne I, Istasse L, Hornick JL 2004: Effects of age on plasma metabolites and hormones in finishing Belgian Blue double-muscled cull females. Anim Sci 78: 229-235

Casasus I, Sanz A, Villalba D, Ferrer R And Revilla R 2002: Factors affecting animal performance during the grazing season in a mountain cattle production system. J Anim Sci 80: 1638-1651

Cavestany D, Blanc JE, Kulcsar M, Uriarte G, Chilibroste P, Meikle A, Febel H, Ferraris A, Krall E 2005: Studies of the transition cow under a pasture-based milk production system: metabolic profiles. J Vet Med A Physiol Pathol Clin Med 52: 1-7

Cooke RF, Arthington JD, Araujo DB, Lamb GC, Ealy AD 2008: Effects of supplementation frequency on performance, reproductive, and metabolic responses of Brahman-crossbred females. J Anim Sci 86: 2296-2309

Coppo JA, Coppo NB, Revidatti MA, Capellari A 2002: Early weaning promotes improvement of blood nutritional indicators in half-bred zebu cows. Livest Res Rural Dev 14: 5

Daix M, Pirotte C, Bister JL, Wergifosse F, Cuvelier C, Cabaraux JF, Kirschvink N, Istasse L, Paquay R 2008 : Relationship between leptin content, metabolic hormones and fat deposition in three beef cattle breeds. Vet $\mathrm{J}$ 177: $273-278$

Doornenbal H, Tong AKW, Murray NL 1988: Reference values of blood parameters in beef cattle of different ages and stages of lactation. Can J Vet Res 52: 99-105

Farver TB 1997: Concepts of normality in clinical biochemistry. II. Reference interval determination and use. In: Kaneko J, Harvey J, Bruss M (Eds), Clinical Biochemistry of Domestic Animals $5^{\text {th }}$ ed. Academic Press, San Diego, pp. 2-9

Fraser MD, Theobald VJ, Davies DR, Moorby JM 2009: Impact of diet selected by cattle and sheep grazing heathland communities on nutrient supply and faecal micro-flora activity Agr Ecosyst Environ 129: 367-377

Grunwaldt EG, Guevara JC, Estevez OR, Vicente A, Rousselle H, Alcuten N, Aguerregaray D, Stasi CR 2005: Biochemical and haematological measurements in beef cattle in Mendoza plain rangelands (Argentina). Trop Anim Health Prod 37: 527-540

Hickey MC, Drennan M, Earley B 2003: The effect of abrupt weaning of suckler calves on the plasma concentrations of cortisol, catecholamines, leukocytes, acute-phase proteins and in vitro interferon-gamma production. J Anim Sci 81: 2847-2855

Chimonyo M, Kusina NT, Hamudikuwanda H, Nyoni O 2000: Reproductive performance and body weight changes in draught cows in a smallholder semi-arid farming area of Zimbabwe. Trop Anim Health Pro 32: 405-415

Kaneko JJ, Harvey JW, Bruss ML 1997: Clinical Biochemistry of Domestic Animals. Acad. Press, New York.

Knowles TG, Edwards JE, Bazeley KJ, Brown SN, Butterworth A, Warriss PD 2000: Changes in the blood biochemical and haematological profile of neonatal calves with age. Vet Rec 147: 593-598

Liker B, Vranesic N, Grbesa D, Bacar-Huskic L, Matic I, Knezevic M, Speranda M, Leto J, Macesic D 2006 : Blood metabolites and haematological indices of beef cattle fed rumen-protected methionin. Acta Vet-Beograd 56: $3-15$

McDowell LR, Hussain A, Ashraf M, Khan ZI, Valeem EE 2005: Seasonal variation of calcium in soil-plantanimal system at sheep ranch, Punjab, Pakistan. Int J Biol Biotechnol 2: 187-195

Myers SE, Faulkner DB, Ireland FA, Parrett DF 1999: Comparison of three weaning ages on cow-calf performance and steer carcass traits. J Anim Sci 77: 323-329

Nazi S, Saeb M, Rowghani E, Kaveh K 2003: The influences of thermal stress on serum biochemical parameters of Iranian fat-tailed sheep and their correlation with tri-iodothryonine (T3), thyroxine (T4) and cortisol concentrations. Comp Clin Pathol 12: 135-139 
Ndlovu T, Chimonyo M, Okoh AI, Muchenje V, Dzama K, Dube S, Raats JG 2009: A comparison of nutritionallyrelated blood metabolites among Nguni, Bonsmara and Angus steers raised on sweetveld. Vet J 179: 273-281

Otto F, Vilela F, Harun M, Taylor G, Baggasse P, Bogin E 2000: Biochemical blood profile of Angoni cattle in Mozambique. Isr J Vet Med 55: http://www.isrvma.org/article/55_3_4.htm

Overton TR, Waldron MR 2004: Nutritional management of transition dairy cows: Strategies to optimize metabolic health. J Dairy Sci 87: 105-119

Parra O, Ojeda A, Combellas J, Gabaldon L, Escobar A, Martinez N, Benezra M 1999: Blood metabolites and their relationship with production variables in dual-purpose cows in Venezuela. Prev Vet Med 38: 133-145

Pavlik A, Zahradkova R, Bures D, Jelinek P, Havlicek Z 2009: Indicators of the internal environment of Gasconne calves during rearing. Acta Vet Brno 78: 37-45

Payne JM 1987: Indicators of protein status. In: Payne JM, Payne S (Eds), The Metabolic Profile Test. Oxford University Press, New York, pp. 27-35

Pereira AMF, Baccari F, Titto ALE, Almeina JAA 2008: Effect of thermal stress on physiological parameters, feed intake and plasma thyroid hormones concentration in Alentejana, Mertolenga, Frisian and Limousine cattle breeds. Int J Biometeorol 52: 199-208

Phillips WA, Juniewicz PE, Zavy MT, Von Tungeln DL 1989: The effect of the stress of weaning and transport on white blood cell patterns and fibrinogen concentration of beef calves of different genotypes. Can J Anim Sci 69: $333-340$

Reynolds CK, Aikman PC, Lupoli B, Humphries DJ, Beever DE 2003: Splanchnic metabolism of dairy cows during the transition from late gestation through early lactation. J Dairy Sci 86: 1201-1217

Ruegg PL, Gooder WJ, Holmberg CA, Weaver LD, Huffman EM 1992: Relation among body condition score, milk production, and serum urea nitrogen and holesterol concentrations in highproduction Holstein dairy cows in early lactation. Am J Vet Res 53: 5-9

Russel AJF, Wright IA: 1983: The use of blood metabolites in the determination of energy status in beef cows. Anim Prod 37: 335-343

Sasaki O, Yamamoto N, Togashi K, Minezawa M 2002: Plasma metabolites concentrations in calves until 90 days of age for estimating genetic ability for milk production traits. Asian-Australasian J Anim Sci 15: 1813-1821

Slobodianik NH, Zago L, Pallaro AN, Feliu MS 1999: Biochemical parameters and nutritional status. Acta Bioquim Clin L 33: 415-427

Suttle N 1993: Overestimation of copper deficiency. Vet Rec 133: 123-124

Thrall MA, Baker C, Campbell TW, Denicola D, Fettman MJ, Lassen ED, Rebar A, Weiser G 2004: Veterinary Haematology and Clinical Chemistry. Lippincott Williams and Wilkins, Philadelphia, 518 p.

Verheyen AJM, Maes DGD, Mateusen B, Deprez P, Janssens GPJ, De Lange L, Counotte G 2007: Serum biochemical reference values for gestating and lactating sows. Vet J 174: 92-98

Whitaker DA, Goodger WJ, Garcia M, Perera BMAO, Wittwer R 1999: Use of metabolite profiles in dairy cattle in tropical and subtropical countries on smallholder dairy farms. Prev Vet Med 38: 119-131

Yokus B, Cakir UD 2006: Seasonal and physiological variations in serum chemistry and mineral concentrations in cattle. Biol Trace Elem Res 109: 255-266 
